Primljen / Received: 20.9.2016. Ispravljen / Corrected: 28.11.2016.

Prihvaćen / Accepted: 17.12.2016. Dostupno online / Available online: 10.1.2017.

\title{
Testing the shear strength of soft rock at different stages of laboratory simulated weathering
}

\section{Authors:}

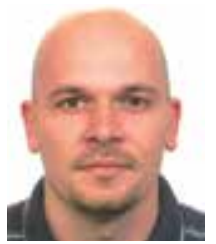

Goran Vlastelica, PhD. CE

University of Split

Faculty of Civil Engineering, Architectureand Geodesy Department of Geotechnical Engineering goran.vlastelica@gradst.hr

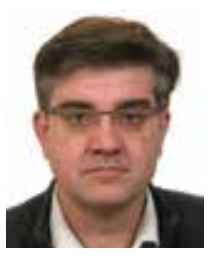

Prof. Predrag Miščević, PhD. CE

University of Split

Faculty of Civil Engineering, Architecture and Geodesy Department of Geotechnical Engineering predrag.miscevic@gradst.hr

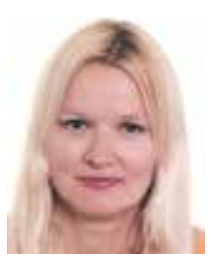

Nataša Pavić, MGE University of Split

Faculty of Civil Engineering, Architecture and Geodesy Department of Geotechnical Engineering nata.pavic@gmail.com
Original scientific paper

Goran Vlastelica, Predrag Miščević, Nataša Pavić

Testing the shear strength of soft rock at different stages of laboratory simulated weathering

Determination of the change in strength based on simulation of weathering process in laboratory conditions is described in the paper, using marl samples taken from flysch formations in the region of Dalmatia. The testing has revealed that the proposed weathering simulation in laboratory can be conducted within acceptable time frames. Because of the observed change of shear strength parameters as related to values corresponding to the strength of material described as soil, it is sometimes necessary to use soil testing devices so as to take into account the load range applied in individual types of testing devices.

Key words:

weathering, soft rock, marl, shear strength, direct shear

Izvorni znanstveni rad

Goran Vlastelica, Predrag Miščević, Nataša Pavić

Mjerenje posmične čvrstoće meke stijene u uvjetima laboratorijski simulirane rastrošbe

U radu je opisano određivanje promjene čvrstoće temeljeno na simuliranju procesa rastrošbe u laboratorijskim uvjetima, koristeći uzorke lapora iz flišne formacije s područja Dalmacije. Na temelju provedenih ispitivanja zaključeno je da je predloženi postupak simuliranja rastrošbe u laboratoriju provediv unutar prihvatljivih vremenskih okvira. Zbog uočene promjene parametara posmične čvrstoće na vrijednosti koje odgovaraju čvrstoći materijala koji se opisuje kao tlo, ponekad je potrebno, zbog raspona veličine opterećenja koje se nanosi u pojedinom tipu uređaja, koristiti i uređaje za tlo.

Ključne riječi:

rastrošba, meka stijena, lapor, posmična čvrstoća, izravni posmik

Wissenschaftlicher Originalbeitrag

Goran Vlastelica, Predrag Miščević, Nataša Pavić

Messungen der Scherfestigkeit weichen Gesteins unter im Labor simulierten Verwitterungsbedingungen

In dieser Arbeit wird die Ermittlung von Änderungen der Scherfestigkeit weichen Gesteins aufgrund simulierter Verwitterungsprozesse unter Laborbedingungen an Mergelproben aus den Flysch-Formationen der Region Dalmatien beschrieben. Aufgrund der Untersuchungen geht hervor, dass das vorgeschlagene Verfahren zur Simulation der Verwitterung im Labor in vertretbarem Zeitrahmen durchgeführt werden kann. Bedingt durch den Einfluss von Änderungen der Scherfestigkeite auf die Festigkeit des Materials, das als Boden beschrieben wird, ist es manchmal notwendig bei großen Unterschieden der aufgebrachten Lasten, je nach Gerätetyp, auch Geräte für Bodenproben zu verwenden.

Schlüsselwörter:

Verwitterung, weiches Gestein, Mergel, Scherfestigkeit, direktes Abscheren 


\section{Introduction}

The durability of rock is defined as the ability to maintain initial mechanical and physical properties in a required period of time with respect to a set of engineering serviceability requirements [1], whether it comes to its impact on construction, other rocks in the geological vicinity, or usability as building material. Soft rocks, when considered as a building material, are subject to intensive change of engineering properties. These changes can be caused by external influences and can manifest within a few months to several years. This durability feature has determined the common concept of soft rock, which is regarded as a material that behaves like a rock in its intact condition, however, when subjected to weathering process, it ultimately degrades to a fine-grained material with a distinct change of physical and mechanical properties compared to its initial state.

Weathering is generally divided into two dominant groups [2]: physical (mechanical) weathering and chemical weathering. Physical weathering results in disaggregation of rocks without mineralogical change, while chemical weathering results in decomposition of constituent minerals to stable or metastable secondary mineral products. Oftentimes, biological weathering is also defined as a group. However, since biological processes can cause physical and chemical changes, it is most often classified in literature as a subgroup of the physical and chemical weathering [3].

Repeated wetting and drying is a dominant process causing degradation of marl in Dalmatia. It is a major cause of physical weathering combined with chemical weathering on the surface of material, as well as on crack walls inside the material, i.e. on all surfaces that are in direct contact with water. Although formally separated, both processes usually occur at the same time and complement each other [4]. Development of cracks during physical weathering increases the surface on which chemical processes are likely to occur. On the other hand, chemical weathering replaces solid minerals with weak clays or pores, which makes the material more susceptible to physical weathering.

In mechanical terms, the degradation of marl manifests itself through reduction of strength. A question arises whether it is possible, following introduction of processes that cause degradation, to measure the trend of this change in strength? The strength of rock is usually expressed through uniaxial compressive strength (UCS) determined in a hydraulic press on cylindrically shaped samples, which is why all known soft rock classifications are based on this parameter [5]. However, this procedure requires a set of monolithic specimens, which is usually difficult to obtain when sampling marl. Some authors [6, 7] suggest a method involving chiselling and sanding of sample sides, which would produce a more ideal specimen. However, these techniques are of no practical use for samples subjected to weathering. Thus, this method is not considered suitable for analysing changes in strength, and an alternative solution should therefore be considered [4].
An alternative way of quantifying strength of this material is to define its shear strength, usually by Mohr-Coulomb shear strength criteria. However, in this case, conventional laboratory equipment is not considered capable of taking into account the entire range of possible occurrences and friability states of marl, and so new equipment should be designed specifically for this type of material [8] or the existing equipment should be adjusted to comply with relevant testing requirements [9]. Since the use of existing equipment is more cost-effective, it is proposed to simplify the experiment by using a portable direct shear apparatus for rocks. With a slight modification of the standard procedure [10], the apparatus would enable soft rock testing in both intact and degraded states of the samples subjected to laboratorysimulated weathering. However, the direct shear apparatus can be used in specific cases (highly weathered marl, subjected to numerous cycles of weathering) [11,12], although it should clearly be specified in which cases this use would be justified.

Knowledge about material strength in all phases of service life of a structure enables its rational design and curbs down maintenance costs. For instance, when designing a construction pit, proper information about atmospheric conditions enables selection of an appropriate solution - stable for the required period of time - without needing to resort to additional slope protection measures [13]. Also, when making side cuts for transport infrastructure or various platforms [14], an optimal slope angle can be selected thus eliminating the need for a protective structure, and so maintenance costs can be reduced significantly during service life of the facility.

\section{Geological aspects in the analysed soft rock area}

The central Dalmatian flysch is a part of a large flysch basin, which stretches from Gorizia in Italy all the way to Albania [15]. Pyrenean orogenic phase of the Eocene epoch is defined as one of the most important phases during the Alpine orogeny. Tectonic movements in this geological period, together with movements in subsequent periods, have resulted in the formation of current geological structures at the eastern coast of the Adriatic Sea [16]. In terms of geodynamics, primary geological structures have significantly been altered by subsequent thrust tectonics.

These tectonic movements have resulted in local narrowing of flysch sedimentary basins in the Adriatic belt and in sporadic occurrence of these rocks on the surface [17], which is especially prominent in central and southern areas of Dalmatia. In central Dalmatia, the flysch rock mass can be found in areas around the towns of Trogir, Kaštela and Split, and these areas are defined in the Basic Geological Map as clastic and carbonate formations of Eocene flysch - $\mathrm{E}_{2,3}$ (Figure 1.).

On the north side, flysch formations are mostly in normal fault contact with Cretaceous limestone of mount Kozjak, while on the south side they spread under the Adriatic Sea. According to lithological characteristics, flysch dominantly consists of clastic sediments classified as limestone breccia, conglomerate, calcirudite, calcarenite and biocalcarenites, calcareous siltstone 


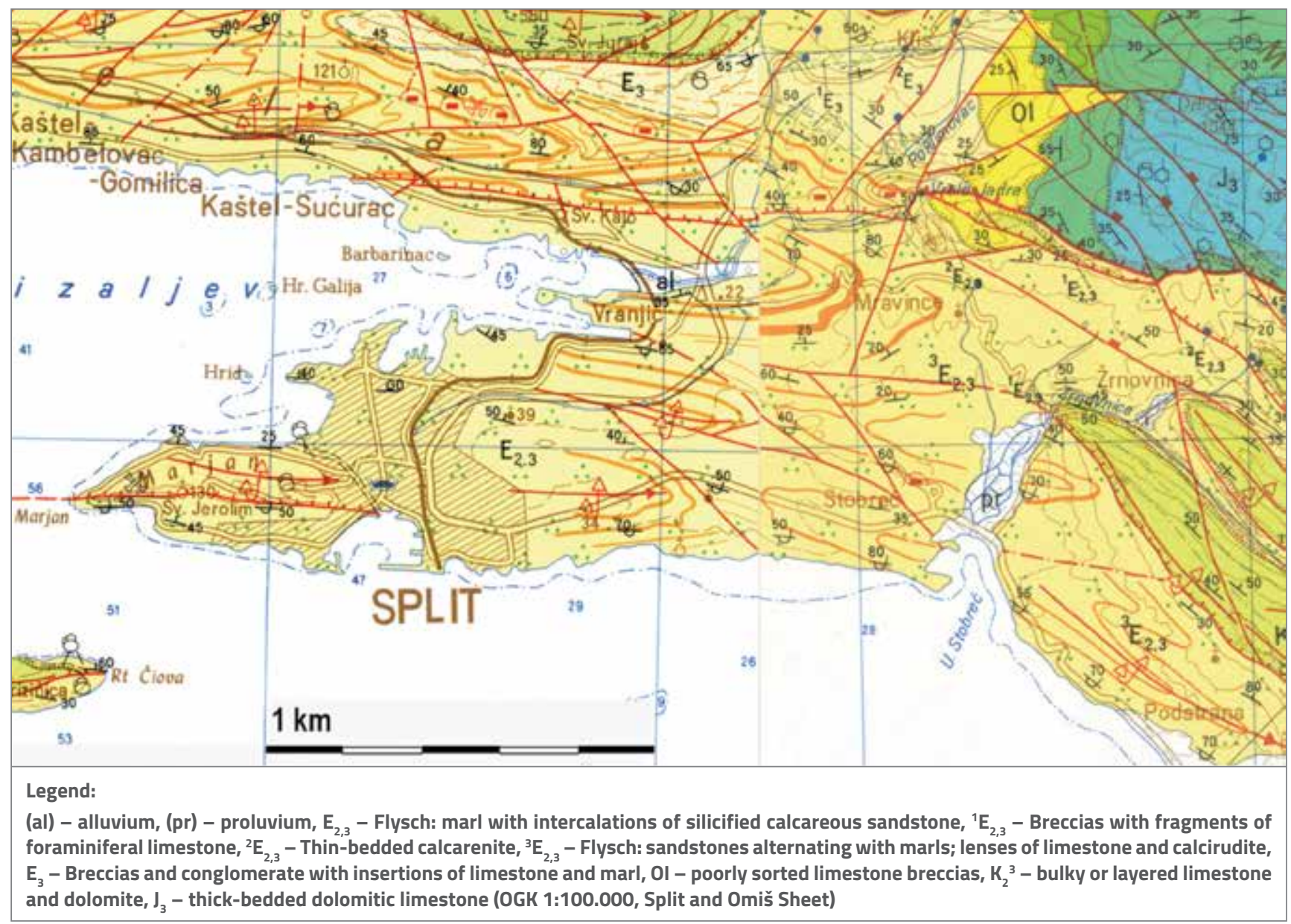

Figure 1. Basic Geological Map of the area around the town of Split (made by Croatian Geological Survey)

and marl. Marl usually manifest as final members in the flysch series, with the registered occurrence of minerals quartz, illite, muscovite, plagioclase, microcline and montmorillonite [18]. According to Šestanović [19], flysch formations in Split area consist of breccia, conglomerate, sandstone, detrital limestone and marl with a varying $\mathrm{CaCO}_{3}$ content. Toševski [20] divided the same members of flysch sequence into: coarse-grained (phaneritic) and fine-grained (argillaceous), wherein coarsegrained members are usually represented by calcirudite and calcarenite, breccias, conglomerates and sandstone, while argillaceous members are represented by marl and siltstone.

Due to their mineral composition, phaneritic layers are more resistant to weathering than argillaceous layers, whose weathering intensity can be noticed on the day to day basis. Because there is such a diversity of members in flysch sequence and, consequently, in their mechanical properties (strength, resistance to weathering, etc.) the problems of durability, differential weathering and local rockfalls are particularly pronounced in side cuts in flysch rock mass [13, 21 - 23].

\subsection{Flysch}

Flysch is a descriptive term for a complex of clastic sedimentary rocks formed by turbid flows, which may be accompanied by sliding of submarine sediments that were previously formed by rapid erosion on land [24]. Because of their sedimentary origin, flysch formations are primarily placed horizontally, however, as a result of tectonic processes, they can usually be found wrinkled or angled. Generally, the flysch complex is mainly characterized by the interchange of coarse and fine-grained sediments.

From the geotechnical aspect, the term "coarse-grained structure" of clastic rocks usually includes psephytes (grain size > $2 \mathrm{~mm}$ ), such as conglomerates and breccia, and psammites (from $2 \mathrm{~mm}$ to $0.06 \mathrm{~mm}$ ) such as sandstone. Fine-grained structures include silts (from 0.06 to $0.002 \mathrm{~mm}$ ) such as siltstone, and pelites (less than $0.002 \mathrm{~mm}$ ) which include marl [25].

\subsection{Marl}

By definition, marl is a rock at the transition between clastic and chemogenic (crystalline) sedimentary rocks since it contains clay size clastic material $(<0.002 \mathrm{~mm}$ ) and carbonate (calcite) extracted from a watery solution. Marl is usually pale yellow, grey, brown or bluish in colour, while its stratification varies from a few centimetres to several meters.

The major part of calcite in marl is chemogenic by origin, formed by secretion from the sea or lake water, while a smaller part may be clastic (calcareous detritus - debris) [26]. Marl is usually 
Table 1. Classification of carbonate rocks depending on their content of calcite and clay components (according to EN 12407: 2007) [27]

\begin{tabular}{|c|c|c|c|c|c|c|c|c|}
\hline \multicolumn{9}{|c|}{$\mathrm{CaCO}_{3}[\%]$} \\
\hline \multicolumn{2}{|c|}{95} & 35 & 65 & 25 & \multicolumn{2}{|l|}{15} & \multicolumn{2}{|l|}{5} \\
\hline limestone & marly limestone & calcareous marl & marl & clayey marl & & marly marl & & clay \\
\hline 0 & & ret & 35 & 75 & 85 & & 95 & 100 \\
\hline
\end{tabular}

considered to be any rock containing 15 to $85 \%$ of clay, 15 to $85 \%$ of carbonate $\left(\mathrm{CaCO}_{3}\right)$, with the corresponding prefixes as described in Table 1.

Marlischaracterized byitsshell-likebreakageand solubilityincold hydrochloric acid (which dissolves calcite), and that fact is mostly used while determining the amount of carbonate content in rock. Although marl is defined as a mixture of clay and calcite, usually some silt to fine sand can be also present. Pure marl consisting only of calcite and clay is relatively rare. Detritus mainly consists of quartz, feldspars, and micas. Marl, which in addition to clay and calcite contains $10-30 \%$ of silt detritus is called silty marl and if it also contains fine sand it is called sandy-silty marl [26]. Marl used in this study has been sampled from the same locations as in previous studies [28]. An average mineral content of the analysed marl samples is: calcite $40-77 \%$, dolomite $0-7 \%$, quartz 3-11\%, plagioclase 1-9\%, chlorite 0-9 $\%$, smectite $6-20 \%$, vermiculite $0-6 \%$ and micaceous minerals 3-12\%. The term "micaceous minerals" is used for a compound probably consisting of illite and interstratified illite-smectite, with some muscovite.

\section{Methodology}

\subsection{Sampling and testing procedure}

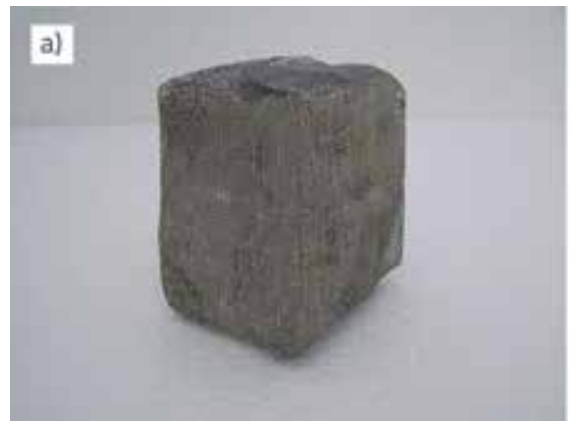

Figure 2. a) Specimen wrapped in net, b) Cutting net in shear plane after specimen is placed in plaster
After analysing all the processes that lead to weathering $[2,29]$, it can be noticed that water has the most significant impact on the development of most of these processes. That longterm impact, through various processes, eventually leads to degradation of mechanical properties of marl. For this reason, the analysis of shear strength degradation, as a representative and most important mechanical property in geotechnical design, is carried out for the impact of the drying and wetting of marl [13] Although the wetting - drying process is dominant, the presented methodology of simulated weathering includes other water induced processes, although they are not necessarily quantified. The main problem of standard testing methods for shear strength determination is the fact that samples quickly disintegrate due to simulated weathering and intense changes in humidity. Therefore, to be able to carry out the test, it is necessary to devise a procedure for specimen preparation, which would allow the use of standardized testing procedure

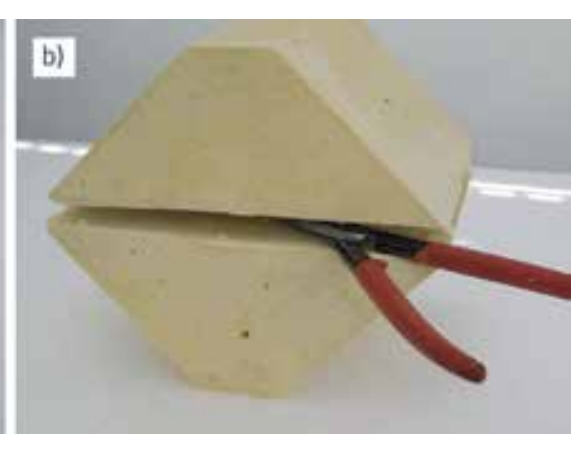

for shear strength, i.e. either a portable device for direct shear walls, or a device for direct shear of soil [10].

Thecollection of samples for testing was conducted in the metropolitan area of the city of Split in freshly excavated cuts, by drilling within the currently performed investigation works, and in excavation pits on construction sites. Collected samples were used to form specimens measuring approximately $6 \times 6 \times 8$ to $10 \times 10 \times 8$ centimetres, which were cut with the stone cutting saw, without the use of water in order to prevent degradation. The main problem encountered when analysing strength degradation caused by deterioration of material due to weathering is to prepare specimen in such a manner that it can be tested after deterioration. Therefore, an addition to standard test is made by enfolding the specimens with a thin metal net during the laboratory-simulated weathering (Figure 2.a).

It was determined during preliminary experiments, in the scope of which square meshes with apertures from 0.5 to $10 \mathrm{~mm}$ were used, that the mesh aperture of $2 \mathrm{~mm}$ is the most suitable for this procedure. The selected aperture is large enough to enable plaster to penetrate the mesh and reach the specimen, and at the same time small enough to prevent material fragments from passing through during the laboratory simulated weathering. After installing the specimen into a portable direct shear device, the net is cut at a predetermined shear plane (Figure 2.b) immediately before the tests, in order to remove any influence of the net strength on test results.

\subsection{Index properties}

Based on literature review, the author's observations and criteria of simplicity and accessibility of laboratory procedure, the following index properties were also determined for every tested sample: 
- Calcium carbonate content - $\mathrm{CaCO}_{3^{\prime}}$

- Water absorption - $\mathrm{w}_{\mathrm{a}^{\prime}}$

- Dry unit weight $-\gamma_{d^{\prime}}$

- Point load index $-I_{s(50)}$

- Slake durability index - SDI [30]

- Loss slake index - LSI [31, 32].

These indicators are used to assess the maximum vertical stress to which the samples would be subjected. Also, they are used for estimating the susceptibility to weathering and therefore to select an appropriate number of cycles of laboratory simulated weathering. Their usability is subsequently analysed.

\subsection{Durability index}

Since the causes of weathering can vary, there is currently no single physical property that can solely describe durability of either one type of rock, or that can enable generalization for all types of rocks. Therefore, many authors have introduced a variety of experiments that can generally be divided into static and dynamic tests. An example of static experiment is the socalled "jar slake test" [33]. The main disadvantage of static experiments is that the results are mostly descriptive and they do not give a numeric value of susceptibility to weathering. For this reason geotechnical engineers prefer dynamic tests such as the "slake durability test" [30]. All durability indices considered in this paper are based on variants of this test (Figure 3).

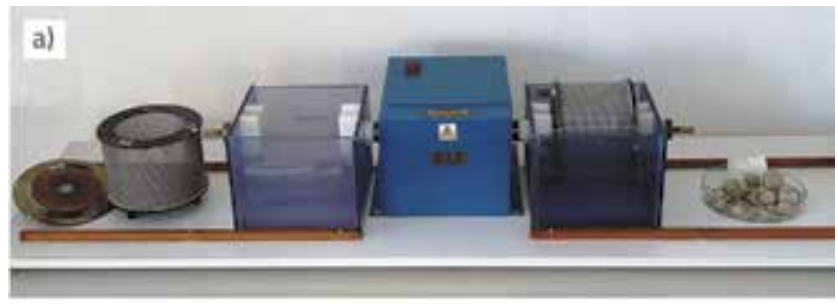

b)

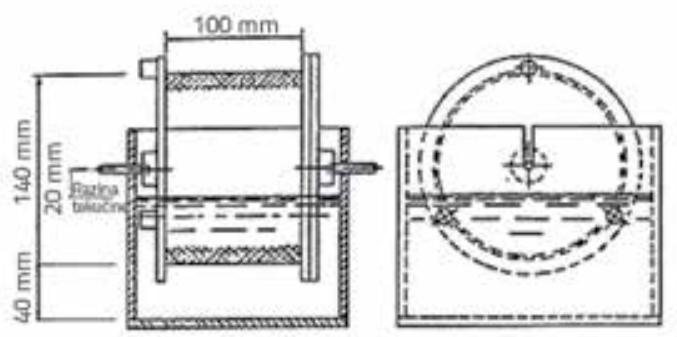

Figure 3. a) Slake durability test device (Geotechnical Laboratory, University of Split); b) Device dimensions (ASTM, D4644-04, 2004)

One specimen for standard slake durability test requires 10 fragments of rock, with a combined weight of approximately $500 \mathrm{~g}$. The fragments should be cube-shaped, with sharp edges evened out. After preparation, the specimen is placed into a standardised drum (Figure 3.b) and it is dried in laboratory oven at constant temperature of 105 degrees centigrade until a constant mass of the specimen is achieved. After drying, the specimen is cooled and weighed to determine its dry mass. The drum is then placed into the device, partially filled with water, and rotated for 10 minutes at $200 \mathrm{rpm}$. After the rotation is finished, the specimen is dried once again and the weight of the remaining material is measured. This procedure can be repeated multiple times, until all the material is deteriorated and the remaining mass is zero. Also, different combinations of rotation time and number of cycles can be defined. At the end of this procedure, the slake durability index $-I_{d n}$ is calculated as follows (1):

$\mathrm{I}_{\mathrm{dn}}=\frac{\mathrm{m}_{\mathrm{n}}}{\mathrm{m}_{0}} \cdot 100[\%]$

where:

$m_{0}$ - the mass of the oven-dried material before the first cycle

$m_{n}$ - the mass of the oven-dried material retained after the $n$ number of cycles.

According to Gamble [30], durability of most rocks can best be defined by means of the durability index, which is calculated after two cycles of the slake durability test - $I_{d 2}$. It can be observed that smaller index values generally indicate softer less durable rock, while higher index values indicate harder more durable rock.

However, current research questions whether this proposed classification is suitable for all types of soft rocks, and whether there is a need for changes or additional criteria [28, 29]. One way to deal with this problem is to increase the number of cycles to four or more, taking one or more values of durability index as relevant. The second approach would be to extend the duration while maintaining a single cycle of rotation, i.e. to select 10,25 , 60 and 120 minutes [31]. In this case, the durability index is calculated as (2):

$S D I_{(\text {time })}=\frac{m_{(\text {time })}}{m_{0}} \times 100[\%]$

where:

$\mathrm{m}_{\text {(time) }} \quad$ - the mass of the oven-dried material retained after the first "time" cycle for a given cycle time

$S D I_{\text {(time) }}$ - the slake durability index for a given cycle time (i.e., $\mathrm{SDI}_{60}$ is the slake durability index for $60 \mathrm{~min}$ ).

Although $\mathrm{SDI}_{\text {(time) }}$ is commonly calculated after one rotation cycle, it is possible to use two or more cycles. This paper uses results obtained after two cycles, which further emphasizes the differences between marl types.

Ratio of $\mathrm{SDI}_{10} / \mathrm{SDI}_{\text {(time) }}$ represents the amount of material that has weathered at a given cycle duration, and is unique for each sample tested in this research. When the ratio of $\mathrm{SDI}_{10} / \mathrm{SDI}_{\text {(time) }}$ is plotted on a time scale, it can be seen that the degree of regression curvature is different for each material. Moreover, it increases as the durability of a rock decreases [31]. Therefore, by using a regression analysis of the data, the relationship 
Table 2. Visual categorization of material remaining after two cycles of slake durability test

\begin{tabular}{|c|l|}
\hline Degradation type & Description \\
\hline I & $\begin{array}{l}\text { After two cycles, the specimen is virtually unchanged (initial 10 pieces), possibly with some fine fragments (10-15 in total) } \\
\text { and with a high value of durability index Id4 (> 95\%) }\end{array}$ \\
\hline II & $\begin{array}{l}\text { After two cycles, the specimen is significantly fragmented (total of 15-50 pieces) and some larger pieces remain } \\
\text { unchanged }\end{array}$ \\
\hline III & After two cycles the specimen is completely fragmented (more than 200 pieces) \\
\hline
\end{tabular}

between aforementioned can be described using a common logarithmic function:

$\log \left(\frac{S D I_{10}}{S D I_{(\text {time })}}\right)=L S I(t-10)$

where the LSI is a new durability index called the Loss Slake Index. The LSI represents the degree of curvature of the regression line in the diagram $\mathrm{SDI}_{10} / \mathrm{SDI} \mathrm{(time)}_{\text {- cycle }}$ duration.

When plotted on a semilog scale, it represents the slope of the line going through $(10,0)$. Unlike the SDI, which is expressed on a scale of 0 to 100 , where low-resistant materials take on lower values and high-resistant higher ones, in the case of highly resistant materials the LSI values are lower (approaching zero), while the low-resistant materials have higher LSI values. Consequently, results are presented in different orders of magnitude (from 0.001 to 10) and are therefore more understandable and easier to interpret.

This research, along the above mentioned indices, uses visual inspection of the material in the drum, which remains after the durability test of two or four rotation cycles (according to ASTM D4644-04, 2004). The procedure is explained in Table 2 and examples are shown in Figure 4.

\subsection{Laboratory simulated weathering}

Weathering activity was simulated with the cycles of wetting and drying in laboratory conditions. A wetting-drying cycle consisted of three phases (Figure 5.):

a) Drying of specimens in an oven at $105^{\circ} \mathrm{C}$ for 24 hours

b) Cooling specimens at laboratory air temperature for 24 hours

c) Immersing specimens in water for 24 hours.

After each cycle of laboratory simulated weathering, the weight of specimen is compared to its initial weight. Some soft rock can be significantly degraded by this procedure, and after a couple cycles they can decompose in such a manner that small particles can pass through mesh aperture. Therefore, it is necessary to ensure that the loss of weight does not exceed $5 \%$ of the initial weight. Specimens that have higher weight loss can not be tested in the portable direct shear box for rocks; therefore a device for direct shear of soil should be used for testing degraded material.

The number of cycles depends on the type of soft rock, i.e. on its susceptibility to weathering. For the purpose of defining the number of cycles, uniaxial compressive strength can be used as an indicator of susceptibility to weathering. However it can also
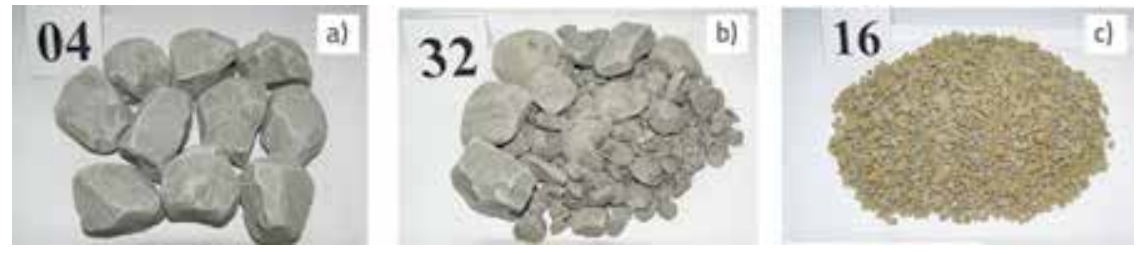
be used as a benchmark on the basis of which the range of vertical loads used in the test is determined. Determination of uniaxial compressive strength for these materials is often impractical (problems with sampling), and so the point load test is used for its assessment. Alongside the point load test, the carbonate content of the sample is also often used as an indicator.
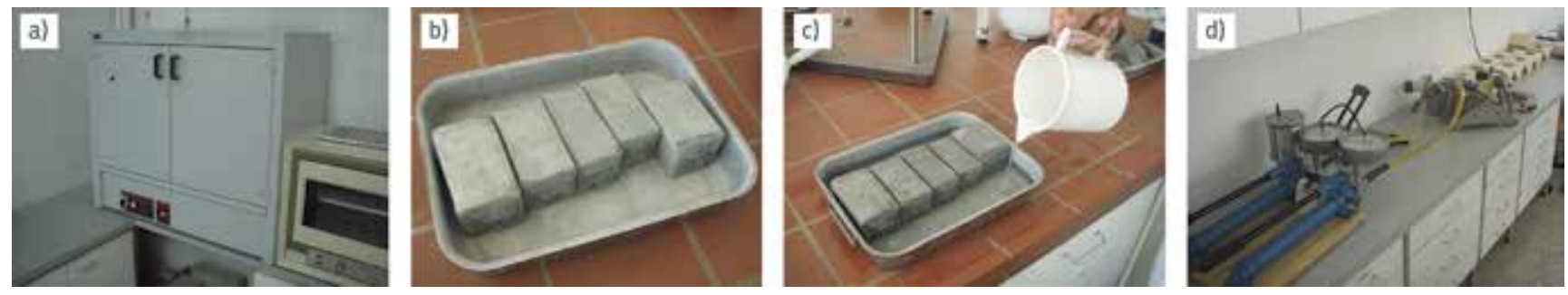

Figure 5. Laboratory simulated weathering by introducing wetting and drying cycles: a) drying of specimens in an oven at $105^{\circ} \mathrm{C}$ for 24 hours; b) cooling specimens at laboratory air temperature; c) immersing specimens in water for $\mathbf{2 4}$ hours; d) after selected number of repetitions of laboratory simulated weathering a-c and placing the specimen in plaster, shearing is performed in the portable direct shear device 
One sample consists of 4 sets of specimens, and each set contains at least 5 test specimens (min. 20 specimens in total). First set was tested in laboratory conditions with moisture preserved and without simulated weathering, whereas the number of wetting and drying cycles was increased for each subsequent series. Two, four, eight, or more cycles were used for samples that can be classified as Type I [28]. One, two and three cycles have proven to be sufficient for Type II. For Type III samples, the testing of weathered specimens was not possible in the portable direct shear box for rocks, except for boundary cases with higher values of carbonate content. Therefore, the use of the device for direct shear of soil for weathered specimens is recommended for Type III samples of marl subjected to laboratory-simulated weathering [11].

\subsection{Shear strength parameters}

Shear strength parameters of marl were determined by direct shear, as recommended by ISRM [10], on an intact rock and at different stages of weathering, with the use of the prescribed procedure and laboratory simulated weathering.

Tests were conducted on specimens that were initially compact, with no detectable cracks (samples taken between two interlayer cracks, which did not contain detectable cracks on the surface). The assessment of the range of normal stress on the shear surface was carried out by examining the carbonate content, durability index and point load test index. Shear strength was analysed according to Mohr-Coulomb's criterion (4):

$\tau_{f}=c+\sigma_{n} \cdot \operatorname{tg} \varphi$

where:

$\tau_{f} \quad$ the peak shear stress

c - the cohesion

$\sigma_{n}-$ an average normal stress

$\varphi$ - the angle of internal friction.

Effective stress is equal to total stress, considering that pore pressure is equal to zero during the entire testing procedure.

\section{Results}

Shear strength parameters for the MohrCoulomb shear strength criterion (4) are presented in Table 3, and an example of data analysis for one test sample is presented in Figure 6. Shear strength parameters are determined by using the least squares method for each series of testing. The number of of wetting-drying cycles is different for each sample. It is defined during the testing depending on the time at which the specimen starts to fall completely apart, or when a sufficient quantity of specimen can not be retained even with the use of net. Values of cohesion which are not consistent with the number of test cycles, are a result of the accuracy of the measuring device or the accuracy of applied interpolation procedure. Also, some inconsistencies can be attributed to the fact that all specimens are not necessarily exactly the same, even if they are taken out of the same sample block (we deal with natural materials).

Shear strength parameters of completely disintegrated marl, which were acquired by testing in the apparatus for direct shear of soil, are presented in Table 4. Two samples were prepared by placing the disintegrated material into the Proctor test cylinder using the optimum moisture content, and the other two were
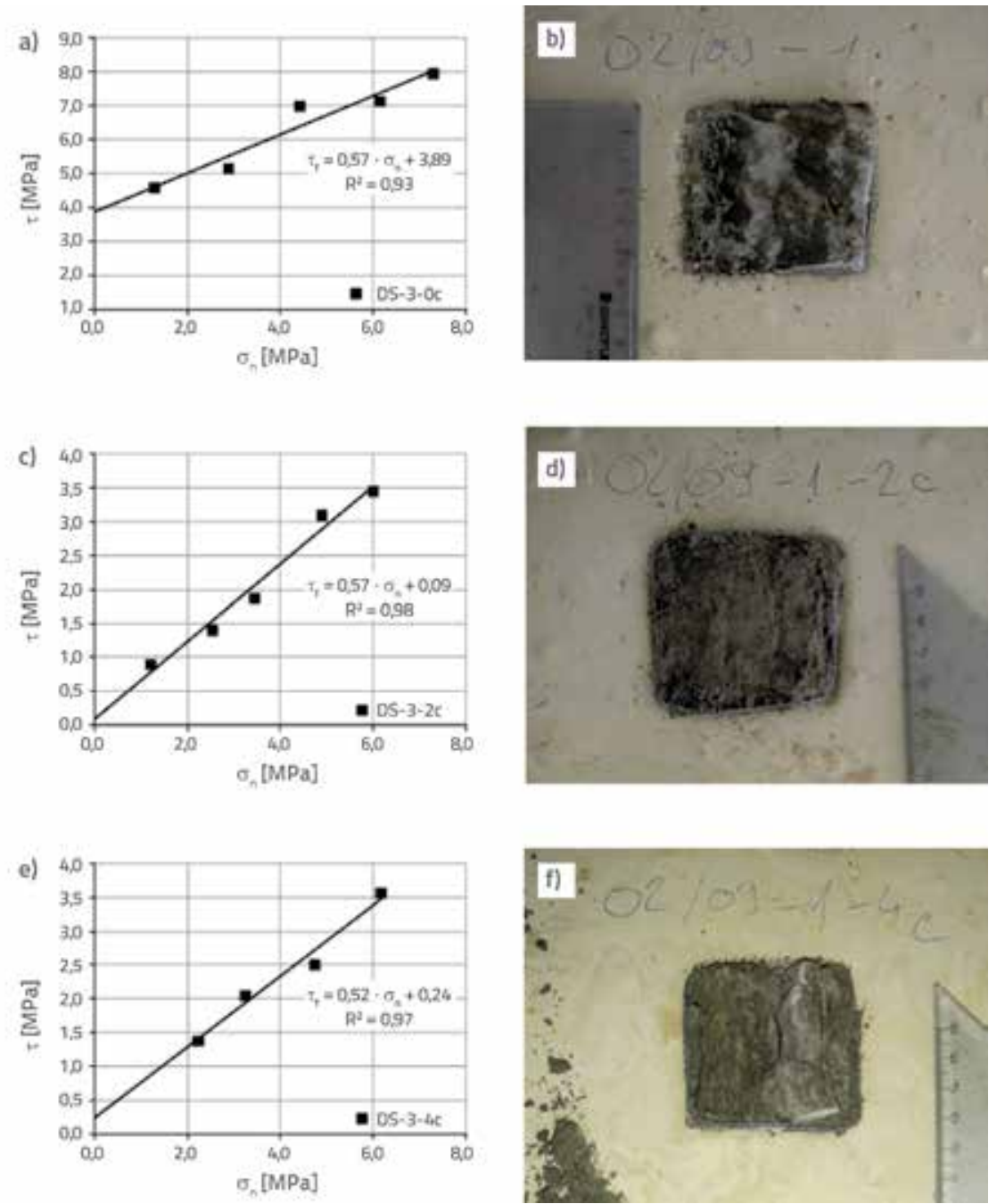

Figure 6. Direct shear test results for sample DS-3, location Trstenik, Split: a) for natural moisture - 0 cycle; b) example of shear plane for natural moisture test; c) after two cycles of laboratory-simulated weathering; d) example of shear plane after two cycles of laboratory simulated weathering; e) after four cycles of laboratory simulated weathering; f) example of shear plane after four cycles of laboratory simulated weathering 
Table 3. Shear strength parameters of marl subjected to laboratory-simulated weathering (test conducted in portable direct shear apparatus for rocks)

\begin{tabular}{|c|c|c|c|c|c|c|c|c|c|c|c|}
\hline \multicolumn{2}{|c|}{ Sample } & DS - 8 & DS - 6 & DS - 7 & DS - 3 & DS - 10 & DS - 9 & DS - 2 & DS - 1 & DS - 4 & DS - 5 \\
\hline \multicolumn{2}{|c|}{$\mathrm{CaCO}_{3}[\%]$} & 40,20 & 44,44 & 49,32 & 54,63 & 63,18 & 65,60 & 69,87 & 71,59 & 76,06 & 77,01 \\
\hline \multicolumn{2}{|c|}{ Upijanje [\%] } & 7,50 & 8,59 & 11,00 & 8,40 & 7,72 & 4,59 & 3,86 & 4,24 & 1,50 & 2,46 \\
\hline \multicolumn{2}{|c|}{$\gamma_{d}\left[\mathrm{kN} / \mathrm{m}^{3}\right]$} & 22,9 & 21,8 & 21,3 & 23,5 & 23,4 & 23,2 & 24,6 & 24,7 & 25,3 & 25,6 \\
\hline \multicolumn{2}{|c|}{$\mathrm{I}_{\mathrm{d} 2}[\%]$} & 98,18 & 89,75 & 88,48 & 76,04 & 78,80 & 97,24 & 98,66 & 98,68 & 98,88 & 98,76 \\
\hline \multicolumn{2}{|c|}{$\mathrm{I}_{\mathrm{d} 4}[\%]$} & 97,23 & 84,11 & 80,17 & 42,22 & 46,76 & 96,37 & 97,8 & 97,7 & 98,27 & 97,98 \\
\hline \multicolumn{2}{|c|}{$I_{s(50)}$} & 0,615 & 1,071 & 0,356 & 0,666 & 1,246 & 1,823 & 1,952 & 1,211 & 3,831 & 2,802 \\
\hline \multicolumn{2}{|c|}{ Tip } & III & II & III & III & III & II & I & I & I & I \\
\hline Cycles & Parameter & & & & & & & & & & \\
\hline \multirow{2}{*}{0} & c [MPa] & & 1,4 & 0,4 & 3,9 & 0,8 & 1,5 & 6,3 & 5,5 & 4,9 & $\mathrm{~N} / \mathrm{A}$ \\
\hline & $\varphi\left[{ }^{\circ}\right]$ & & 29,7 & 34,4 & 29,6 & 36,8 & 46,1 & 40,0 & 40,9 & 49,0 & \\
\hline \multirow{2}{*}{1} & c [MPa] & & 0,2 & \multirow{8}{*}{$\stackrel{\wp}{\vDash}$} & - & 0,0 & - & - & - & - & \\
\hline & $\varphi\left[^{\circ}\right]$ & & 37,1 & & - & 37,8 & - & - & - & - & \\
\hline \multirow{2}{*}{2} & c [MPa] & $\unrhd$ & 0,1 & & 0,1 & - & 1,3 & 4,6 & 2,2 & 5,2 & \\
\hline & $\varphi\left[^{\circ}\right]$ & & 36,4 & & 29,7 & - & 39,5 & 34,4 & 39,3 & 44,8 & \\
\hline \multirow{2}{*}{4} & c [MPa] & & 0,1 & & 0,2 & \multirow{4}{*}{$\stackrel{\Re}{\models}$} & 1,1 & - & - & N/A & \\
\hline & $\varphi\left[{ }^{\circ}\right]$ & & 25,0 & & 27,7 & & 41,7 & - & - & & \\
\hline \multirow{2}{*}{8} & c [MPa] & & - & & 0,2 & & 0,6 & - & - & & \\
\hline & $\varphi\left[^{\circ}\right]$ & & - & & 31,2 & & 43,8 & - & - & & \\
\hline \multicolumn{12}{|c|}{$\begin{array}{l}\text { N/A - testing was dismissed because of immobilisation plaster cracking at more than } 60 \% \text { of specimens in one set. } \\
\text { T/B - upper part of shear box rested on the bottom part (large vertical deformation of the specimen took place under compressive force) and the } \\
\text { results were discarded. }\end{array}$} \\
\hline
\end{tabular}

Table 4. Shear strength parameters of marl subjected to laboratory simulated weathering (test conducted in direct shear apparatus for soil)

\begin{tabular}{|l|c|c|c|c|c|c|c|}
\hline Sample & $\begin{array}{c}\mathrm{CaCO}_{3} \\
{[\%]}\end{array}$ & $\begin{array}{c}\mathrm{I}_{\mathrm{d} 2} \\
{[\%]}\end{array}$ & $\begin{array}{c}\mathrm{W}_{\mathrm{a}} \\
{[\%]}\end{array}$ & $\begin{array}{c}\mathrm{W}_{\mathrm{opt}} \\
{[\%]}\end{array}$ & $\begin{array}{c}\mathrm{c} \\
{[\mathrm{kPa}]}\end{array}$ & $\begin{array}{c}\varphi \\
{\left[{ }^{\circ}\right]}\end{array}$ & Remark: \\
\hline DSS - 20 (Proctor) & 64,3 & 72,8 & 9,8 & 14,2 & 17,7 & 25,2 & sieved through a 0,85 mm sieve \\
\hline DSS - 20 (sediment) & & & & & 3,8 & 23,7 & SDI test sediment \\
\hline DSS - 21 (Proctor) & 49,8 & 26,4 & 20,8 & 14,3 & 1,5 & 26,3 & sieved through a 0,85 mm sieve \\
\hline DSS - 21 (sediment) & & & & & 0,2 & 18,6 & SDI test sediment \\
\hline
\end{tabular}

collected as sediment remaining from the slake durability test. The sediment was formed with an extended operation of the testing machine, until a sufficient quantity of sample was generated for installing four specimens into the cell for the direct shear of soil. After the specimens had been consolidated under their own weight for 24 hours, they were tested according to the standard procedure for direct shear of soil [11].

\section{Discussion}

According to results shown in Table 3 for samples DS-1, DS-2, DS-4 and DS-5, which have carbonate content in the range of 70-77\% and can be classified as Type I according to durability analysis, it is evident that the results for intact specimens with natural moisture are consistent with the results of the investigations and tests that have previously been conducted in this area, For instance, in their paper "Engineering Geological Research of Flysch in the Housing Developments of Pujanke, Split" [34], Šestanović et al. present average values of shear strength parameters of marl (Table 5) with $\mathrm{CaCO}_{3}>75 \%$, which amount to $\varphi=48^{\circ}$ and $\mathrm{c}=3 \mathrm{MPa}$, while for marls with the $\mathrm{CaCO}_{3}$ in the range of $65-75 \%$ these values are $\varphi=40^{\circ}$ and $c$ $=2 \mathrm{MPa}$.

Type I samples with a smaller $\mathrm{CaCO}_{3}$ content (DS-1 and DS-2) reveal a trend of decrease in shear strength after two cycles of simulated weathering, while there is no significant change in same sample type with a higher $\mathrm{CaCO}_{3}$ content. Moreover, because of the high strength of marl, many specimens exhibit plaster breakage, and so the series in which this issue was manifested in at least three tests were discarded (N/A). 
Table 5. Shear strength parameters of intact marl from "Engineering Geological Research of Flysch in the Housing Developments of Pujanke, Split", [34]

\begin{tabular}{|c|c|c|c|c|}
\hline \multirow{2}{*}{ Parameter } & \multicolumn{4}{|c|}{ Calcium carbonate content $\mathrm{CaCO}_{\mathbf{3}}[\%]$} \\
\cline { 2 - 5 } & $\mathbf{7 5}$ & $\mathbf{7 5 - 6 5}$ & $\mathbf{6 5} \mathbf{- 5 0}$ & $\mathbf{5 0 - 3 5}$ \\
\hline Cohesion c $[\mathrm{kPa}]$ & 3000 & 2000 & 1100 & 100 \\
\hline $\begin{array}{c}\text { Angle of internal } \\
\text { friction } \varphi\left[^{\circ}\right]\end{array}$ & 48 & 40 & 28,5 & 20 \\
\hline $\begin{array}{c}\text { Unit weight of } \\
\text { marl } \gamma\left[\mathrm{kN} / \mathrm{m}^{3}\right]\end{array}$ & 24,0 & 24,0 & 24,0 & 18,5 \\
\hline
\end{tabular}

For samples DS- 6 and DS- 9 with the $\mathrm{CaCO}_{3}$ content of $44.4 \%$ and $65.6 \%$ which, according to durability analysis, can be classified as Type II, it is also evident that the results without simulated weathering are consistent with the data from literature [34]. For sample DS-6, it can be observed that an increasing number of cycles of simulated weathering did not produce the expected consequent drop in strength (according to the angle of internal friction). Visual inspection of the degraded specimen revealed some secondary cracking (Figure 7.), which was not present on the specimen surface before the test.
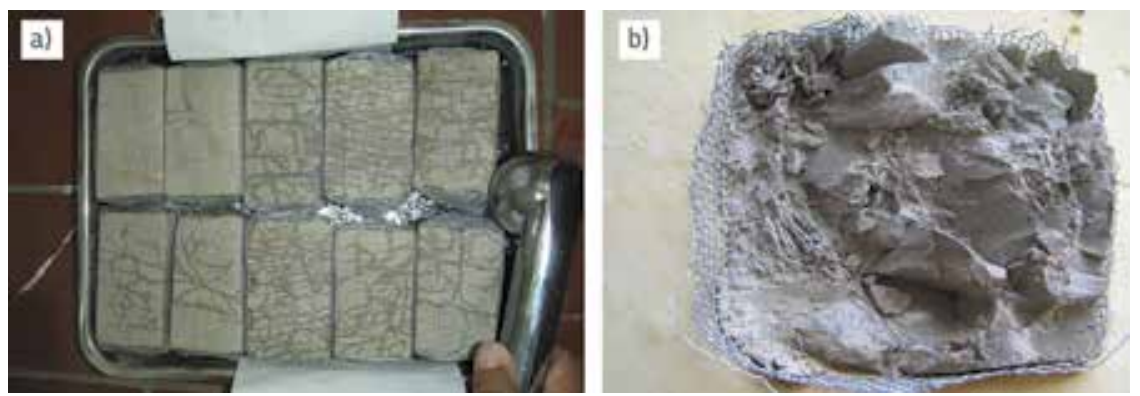

Figure 7. a) Sample DS-6 (before installation) during initial wetting in second cycle of laboratory simulated weathering; b) Example of shear surface for sample DS- 6 after two cycles of weathering
An increase in friction angle after the first cycle of wetting-drying is also typical of these samples. Visual inspection after testing showed that the specimens are usually split into a number of large fragments (Figure 7.a), however, without weakening (or decomposition) of material in the centre (Figure 7.b). Some fragments detached from the surface of the displayed sample due to disassembly of the cell and so a continuous shear surface is not clearly visible. This sample could be described as well graded compacted gravel, which might explain an increase in friction angle.

For sample DS-9, it can be noted that the expected consequent decrease of the internal friction angle did not take place with an increasing number of wetting and drying cycles. Its characteristics can be described in a similar manner as for samples DS-1 and DS-2, especially with respect to its carbonate content of $65.6 \%$, regardless of the fact that it is classified as Type II.

Samples DS-3, DS-7, DS-8 and DS-10 with carbonate content ranging from $40.2 \%$ to $63.2 \%$, classified as Type III according to their durability, also show that the results for intact specimens with natural moisture are consistent with the data from literature $[9,13,34]$. For samples DS-3 and DS-10, with the carbonate content of $54.63 \%$ and $63.18 \%$, respectively, it is interesting to note that the angle of internal friction remains almost the same even after application of wetting-drying cycles, which corresponds to values obtained by testing a number of other marl samples with similar carbonate content. On the other hand, cohesion changes significantly after the first few cycles of wetting-drying and, afterwards, there is no change in the order of magnitude regardless of the number of cycles applied. For larger number of cycles there is a problem of seating of the top part of the shear box onto the bottom part, when a higher value of normal stress is applied. For samples DS-7 and

Table 6. Guidelines for laboratory-simulated weathering of soft rocks

\begin{tabular}{|c|c|c|c|c|}
\hline \multirow[b]{2}{*}{ Type } & \multicolumn{2}{|c|}{$\begin{array}{l}\text { Applicability of portable direct shear } \\
\text { apparatus }\end{array}$} & \multicolumn{2}{|r|}{ Laboratory simulated weathering procedure } \\
\hline & $\begin{array}{l}\text { Unweathered } \\
\text { material }\end{array}$ & $\begin{array}{c}\text { Laboratory } \\
\text { weathered } \\
\text { material }\end{array}$ & $\begin{array}{l}\text { Recommended } \\
\text { max number of } \\
\text { cycles }\end{array}$ & Remark \\
\hline Type I & Yes & Yes & $>8$ & - \\
\hline Type II & Yes & Yes & to $8\left(4^{*}\right)$ & $\begin{array}{l}\text { For a larger number of cycles it is recommended to use the device for } \\
\text { direct shear of soil }\end{array}$ \\
\hline Type III & Yes & Limited & $1^{* *}$ & It is recommended to always use the device for direct shear of soil \\
\hline \multicolumn{5}{|c|}{$\begin{array}{l}\left.\text { * For Type II marl bordering with Type III (generally with smaller } \mathrm{CaCO}_{3} \text { content or } \mathrm{LSI} \approx 0,5\right) \text { maximum of } 4 \text { cycles of laboratory simulated weathering is } \\
\text { recommended. } \\
\text { ** - For direct shear of intact rock, use the direct shear apparatus for rock. Testing of degraded material is usually impossible, and the use of direct shear apparatus } \\
\text { for soil is recommended. } \\
\text { *** - When selecting proper procedure, it is always recommended to use information about } \mathrm{CaCO}_{3} \text { content, absorption, Id4 and LSI index of rock [32]. If it can be } \\
\text { concluded from such information that it is a borderline sample between two categories, then the use of a higher-category method is recommended and, if } \\
\text { necessary, the procedure may be corrected during the testing. }\end{array}$} \\
\hline
\end{tabular}


DS-8, with a carbonate content of $49.32 \%$ and $40.20 \%$, this problem becomes evident even when conducting tests without simulated weathering, and so the testing must be performed with a larger number of samples to compensate. In addition, simulated weathering tests could not be performed in the direct shear box for rocks.

Samples that remain sufficiently stable after simulated weathering, i.e. samples suitable for testing, exhibit shear strength results that are close to the values obtained for the marl clay [13] and degraded marl tested in the device for direct shear of soil (Table 4).

\section{Conclusion}

Shear strength tests conducted in the scope of this study are insufficient for forming a statistically representative sample correlating with index properties. On the other hand, they are representative for preparing draft guidelines for determination of shear strength of soft rocks, such as marl, at different stages of weathering. Taking into account significant quantity of sample required for one testing, as well as the time requirement (about 25 days for one series of tests), the results obtained represent a significant contribution for improving testing methodology, as a basis for understanding behaviour of marl in complex engineering situations.

Shear strength parameters for intact sample were determined on groups of specimens at different stages of weathering, which involved some additions to standardized testing procedure and laboratory-simulated weathering. Test results point to the grouping of samples consequent with the categorization proposal shown in Table 2, with some restrictions in borderline cases, as described in notes to Table 6.

Finally, it can be concluded that the proposed procedure of laboratory simulated weathering is feasible and that the time frames for such procedure are acceptable. The testing can be carried out in a portable direct shear apparatus for rock, with restrictions for Type III marl, where the device for direct shear of soil is recommended for laboratory testing of weathered material.

\section{Acknowledgement}

The above results have been derived from the research project "Developing of weathering model for geotechnical constructions in flysch", conducted under the aegis of the Ministry of Science, Education and Sport of the Republic of Croatia.

\section{REFERENCES}

[1] Latham, J.P., Wang, H., Poole, A.B.: Choice of rock in maritime engineering, Coastal, Estuarial and Harbour Engineers Reference Book, Editors: Abbott, Price, Publisher: Chapman and Hall, pp. 523 $-539,1993$

[2] Fookes, P.G., Gourley, C.S., Ohikere, C.: Rock weathering in engineering time, Quar. J. of Eng. Geol, 21 (1988), pp. 33 - 57, https://doi.org/10.1144/GSL.QJEG.1988.021.01.03

[3] Gulam, V.: Erozija ogolina u flišu središnje Istre, Doktorski rad, Sveučilište u Zagrebu, Rudarsko - geološko - naftni fakultet, Zagreb, 2012.

[4] Miščević, P., Vlastelica, G.: Shear strength of weathered soft rock - proposal of test method additions. Proc. Reg. Sym. on Rock Eng. in Diff. Gr. Cond. - Eurock 2009, Cavtat, Croatia, pp. 303 - 308. Leiden: CRC Press/Balkema, 2009.

[5] Kanji, M.A.: Critical issues in soft rocks, Journal of Rock Mechanics and Geotechnical Engineering, 6 (2014), pp. 186-195, https://doi. org/10.1016/j.jrmge.2014.04.002

[6] Agustawijaya, D.S.: The Uniaxial Compressive Strength of Soft Rock, Civil Engineering Dimension, 1 (2007) 9, pp. 9-14.

[7] Akai, K.: Testing methods for indurated soils and soft rocks Interim report, Geotechnical Engineering of Hard Soils - Soft Rocks, Anagnostopoulos et al. (Eds.), Balkema, pp. 1707 - 1736, 1997.

[8] Zhang, B.Y., Zhang, J.H., Sun, G.L.: Development of a Soft - Rock Weathering Test Apparatus. Experimental Techniques, 38 (2014) 2, pp. $54-65$.

[9] Miščević, P., Vlastelica, G.: Shear strength of artificially weathered marl. Proc. Reg. Sym. on Rock Mechanics in Civil and Environmental Engineering - Eurock 2010, Lausanne, Switzerland, pp. 119 - 122, Leiden: CRC Press/Balkema, 2010.
[10] ISRM, Suggested methods for determining shear strength, 1974.

[11] Roje - Bonacci, T.: Parameter changes after weathering of soft rock in flysch, Proc. Int. Sym. on Hard Soils - Soft Rock, Naples, Italy, pp. $799-804,1998$.

[12] Vivoda Prodan, M., Mileusnić, M., Mihalić Arbanas, S., Arbanas, Ž.: Influence of weathering processes on the shear strength of siltstones from a flysch rock mass along the northern Adriatic coast of Croatia, Bulletin of Engineering Geology and the Environment, pp. 1-17, 2016, https://doi.org/ 10.1007/s10064 - 016 - 0881 - 7

[13] Miščević, P., Vlastelica, G.: Stabilnost u vremenu kosine iskopane u laporu, Građevinar, 64 (2012) 6, pp. 451 - 461.

[14] Berisavljević, Z., Berisavljević, D., Čebašek, V.: Shear strength properties of Dimitrovgrad flysch, Southeastern Serbia, Bulletin of Engineering Geology and the Environment, 74 ( 2015) 3, pp.759 773.

[15] Marinčić, S.: Eocenski fliš jadranskog pojasa. Geološki vjesnik, Zagreb, 34 (1981), pp. 27 - 38.

[16] Korbar, T.: Orogenic evolution of the External Dinarides in the NE Adriatic region: a model constrained by tectonostratigraphy of Upper Cretaceous to Paleogene carbonates, Earth - Science Reviews, 96 (2009), pp. 296-312, https://doi.org/10.1016/j. earscirev.2009.07.004

[17] Velić, I., Vlahović, I.: Geološka karta Republike Hrvatske 1:300.000. Geološki institut, Zagreb, 2009.

[18] Marinčić, S., Magaš, N., Borović, l.: Osnovna geološka karta - Tumač za listove Split i Primošten. Institut za geološka istraživanja, Zagreb, 1967. 
[19] Šestanović, S.: Engineering - geological characteristics of marl from Eocene flysch in the City of Split, Croatia. The Geotechnics of Hard Soils - Soft Rocks, Evangelista i Picarelli (eds.), Balkema, Rotterdam, pp. 311 - 314, 1998.

[20] Toševski, A., Grgec, D., Padovan, D.: Osnovno o genezi, sastavu i trošenju eocenskog fliša hrvatskog obalnog pojasa. Rudarsko geološko - naftni zbornik, 25 (2012), pp. 47 - 62.

[21] Eberhardt, E., Thuro, K., Luginbueh, M.:Slopeinstabilitymechanisms in dipping interbedded conglomerates and weathered marls - the 1999 Rufi landslide, Switzerland. Engineering Geology, 77 (2005), pp. 35-56, https://doi.org/10.1016/j.enggeo.2004.08.004

[22] Martinez - Bofill, J., Corominas, J., Soler, A.: Behaviour of the weak rock cut slopes and their characerization using the results of the slake durability test, Proc, Engineering geology for infrastructure planning in Europe - a Europian perspective, pp. 405 - 413, 2004.

[23] Šestanović, S., Štambuk, N., Samardžija, l.: Control of the Stability and Protection of Cut Slopes in Flysch. Geolog. Croat., 47 (1994) 1, pp. $139-148$.

[24] Vlahović, T.: Geologija za građevinare. Sveučilište u Splitu, Građevinsko - arhitektonski fakultet. pp. 295, 2010.

[25] Šestanović, S.: Osnove geologije i petrografije. Građevinski fakultet Sveučilišta u Splitu, 2001.

[26] Tišljar, J.: Petrologija sedimentnih stijena. Rudarsko geološko naftni fakultet Sveučilišta u Zagrebu, pp. 242, 1987.

[27] ISRM Turkish National Group: The complete ISRM Suggested methods for Rock Characterization, Testing and Monitoring: 1974 2006. Ulusay, R., Hudson J.A. (Editors). Ankara, Turkey, 2007.
[28] Miščević, P., Vlastelica, G.: Durability Characterization of Marls from the Region of Dalmatia, Croatia. Geotechnical and Geological Engineering, 29 (2011), pp. 771 - 781, https://doi.org/10.1007/ s10706-011-9416-y

[29] Gökçeoğlu, C., Ulusay, R., Sönmez, H.: Factors affecting the durability of selected weak and clay - bearing rocks from Turkey, with particular emphasis on the influence of the number of drying and wetting cycles, Engineering Geology, 57 (2000), pp. 215 237, https://doi.org/10.1016/S0013-7952(00)00031-4

[30] Gamble, J.C.: Durability - plasticity classification of shales and other argillaceous rock. Ph.D. thestis, University of Illinois, 1971.

[31] Bryson, L.S., Gomez - Gutierrez, I.C., Hopkins, T.C.: Development of a New Loss Slake Durability Index for Compacted Shales, Engineering Geology, 139 - 140 (2012), pp. 66 - 75.

[32] Vlastelica, G., Miščević, P., Salvezani, D.: Loss slake index evaluation and its applicability to marl. EUROCK 2013 - Rock Mechanics for Resources, Energy and Environment, Kwasniewski, M., Lydzba, D. (Editors), Taylor \& Francis Group, London, UK, pp. 363 - 367, 2013.

[33] Santi, P.M.: Improving the jar slake, slake index, and slake durability tests for shales. Environmental and Engineering Geoscience, 4 (1998) 3, pp. 385 - 396.

[34] Šestanović, S., Čagalj, M., Barčot, D., Urli, M.: Geotehnički radovi za temeljenje naselja "Pujanke" u Splitu, Građevinar, 36 (1983) 9, pp. $371-376$. 